\title{
THE EFFECT OF WOOD SPECIES ON THE ANTI-SKID RESISTANCE OF COATINGS
}

\author{
Isabel Fernández ${ }^{1, \star}, M^{a}$ Ángeles Fernández ${ }^{1}$, Katia Rodríguez ${ }^{1}$, Vanessa Baño ${ }^{1}$, Andrés Dieste ${ }^{1}$
}

\begin{abstract}
The anti-skid resistance of six coatings (Alfa, Beta, Gamma, Lambda, Mu and Theta) designed for outdoor wood flooring were tested in chestnut (Castanea sativa Mill.) and pine (Pinus pinaster Ait.) using a Portable Skid Resistance Tester according to standard ENV 12633. Film thickness, coating retention level, and presence of mineral particles were determined for each coating. Furthermore, the liquid water absorption coefficient of chestnut was determined in accordance with standard UNE-EN 1609 , to relate all parameters.

The highest value of skid resistance in both chestnut and pine was obtained with coating $\mathrm{Mu}(49.75)$ and coating Gamma (53.16), respectively. Film thickness and coating retention level were consistently higher for pine than for chestnut. Gamma presented the highest presence of minerals. For chestnut the absorption coefficient of liquid water in the tangential direction was $0.0056 \pm 0.0010 \mathrm{~kg} \cdot \mathrm{m}^{-2} \cdot \mathrm{s}^{-0.5}$, considerably lower than the value found for pine: $0.011 \mathrm{~kg} \cdot \mathrm{m}^{-2} \cdot \mathrm{s}^{-0.5}$. The different performance of the system wood-coating, and consequently the anti-skid resistance, was attributed to the absorption properties of the different species.
\end{abstract}

Keywords: Outdoor flooring, coatings, skid resistance, film thickness, chestnut

\section{INTRODUCTION}

A common problem in outdoor wood flooring is the risk of accidents due to slipping. Skid resistance is the property of a surface to provide a pedestrian with a safe grip; it depends on the surface material, and design, the shoe sole worn by the pedestrian and the condition of the surface (dry or wet) (Medina 2005). Skid resistance is determined using a Portable Skid Resistance meter, which consists of a pendulum with a rubber-coated foot piece which oscillates on the sample to test. The pendulum is stopped by the friction between the rubber and the sample. The maximum oscillation is indicated on a scale from 0 to 150 (there are no units involved) with a high value indicating high anti-skid resistance.

A combination of chemical (solar degradation, lixiviation, temperature, etc.), biological (fungi and mosses) and mechanical processes (flooring wear due to traffic) develop a set of reactions that finally contribute to the surface degradation, which is followed by the increasing risk of skid and probable falls. The Spanish Construction Regulations (C.T.E.-D.B.-S.U) requires that the skid resistance of outdoor flooring must be higher than 45. A common method to increase the outdoor performance of wood floorings is the application of anti-skid resistance coatings. The selected wood species should prove to be effective during the service life of the flooring. Currently in Northern Spain there is interest in using chestnut wood, an abundant local wood species, for construction purposes. The coating performance of a wood species is affected by the following properties: density, dimensional stability, anatomical features and chemical composition, among others. The following table presents the information for chestnut and pine, the latter used as reference (Table 1). 
Table 1. Characteristics of chestnut (Castanea sativa) and pine (Pinus radiata)

\begin{tabular}{lll}
\hline Characteristics & Chestnut & Pine \\
\hline Density $\left(\mathrm{gcm}^{-3}\right)$ & 0.59 & 0.47 \\
Tangential contraction $(\%)$ & 6.3 & 7.4 \\
Radial contraction $(\%)$ & 4.3 & 4.2 \\
Fibre saturation point $\left(\right.$ at $\left.22^{\circ} \mathrm{C}\right)$ & 22.9 & 30.4 \\
Texture & Coarse & Fine \\
Grain & Coarse & Average-coarse \\
Exudates and extracts & High content & Average-content \\
\hline
\end{tabular}

Popper et al. 2005, Vignote et al. 2000, Vignote and Martinez 2006.

High density woods have a lower void space (pores) between wood elements, which has an effect on the absorption of the coating. The amount of pores varies greatly depending on the species. Furthermore, their size, shape and frequency are determined by the cut of the exposed surface (tangential and radial). Commonly, coniferous wood is more porous than the wood of deciduous species; in addition, the pores of coniferous wood are more uniformly distributed (Martin 1997).

Moisture content is a critical factor to consider, since wood is a hygroscopic material. Water fills the void space in wood, resulting in a physical obstacle for the absorption of the coating. Furthermore, high moisture content prevents the cross linking of polymers and produces defective drying which causes a lack of adherence of the coating. For appropriate application and correct subsequent coating drying, the amount of moisture should not exceed 20\% (Martin 1997). Therefore, it is important to consider the fiber saturation point (FSP), namely the moisture content at which the cell wall is saturated with moisture. This property varies greatly between species, and normally is lower in species with a high content of extractives (Spalt 1958).

The presence of extractives in wood affects the absorption of the coatings and its curing on the surface of the wood. During the drying of wood the extractives are transported to the surface in a heterogeneous distribution, causing their concentration in certain parts of the boards. In addition, heated wood releases exudates that interfere with absorption, curing, and anchorage of coatings. Conifer woods are rich in resinous substances, whereas deciduous wood are richer in tannins (Martin 1997).

Furthermore a radial cut has greater dimensional stability compared with a tangential cut. Therefore, a radial cut results in a better coating finish than a tangential cut. This fact shows the advantages of using wood species with a low coefficient of volumetric contraction (Tamatir-Urias et al. 2002).

Wood finishes and their final behavior can be described as a three component system: wood, coating and the relations coatings-wood. The final result not only depends on the anatomical properties of each species, but also the characteristics of the different coatings. An important parameter in the performance of coatings is the capability to penetrate the wood structure. Several methods have been applied and tested to investigate the penetrating ability of coatings in wood, and the different cellular distribution of it by techniques of X-ray analysis and means of florescence microscopy. Penetration of coating into wood is first of all determined by the ability of the paint to flow into the open ends of the cell capillaries (de Meijer 1998).

Differences in penetration depth are influenced by the paint system, the type of binder, particle size of the binder, and type of solvent (Rijckaert et al. 2001). Generally the waterborne coatings penetrate less deeply into the wood structure than the solvent-borne coatings, although large differences between water-borne coatings exist, depending on the type of formulation used (de Meijer 2001). In addition, de Meijer (1998) concludes that the type of binder has the biggest effect on wood penetration, with the following increasing order in penetration: acrylic dispersion, alkyd emulsions, solvent borne alkyds and high solid alkyds. 
Moreover, in relation with the different cellular distribution of coatings within the structure of the wood, the axial penetration is deepest in the solvent based coatings, and in the water borne the penetration is deepest in the wider earlywood cells, whereas for the solvent borne coatings the situations is reverse. This might indicate that the basic flow mechanisms are different in water and solvent based coatings (Rijckaert et al. 2001).

The combination of viscosity, surface tension, drying rate of the coating and the diameter of the wood pores determine the penetrating capacity of coating. With lower viscosity and lower surface tension the penetration becomes deeper (Rijckaert et al. 2001).

The objective of this study was to evaluate the effect of species in the performance of six different outdoor coatings with anti-skid properties using: pine (Pinus pinaster Ait.), as reference, and chestnut (Castanea sativa Mill.).

\section{MATERIAL AND METHODS}

154 samples of chestnut wood (Castanea sativa Mill.) and 154 of pine wood (Pinus pinaster Ait.) were used in the experiment. Five different coatings offered in the Spanish market were chosen according to the following criteria: anti-skid abilities, color, ease of application and price. A common open-pore finish with no anti-skid properties was also tested as a reference (Table 2).

Table 2. Description of anti-skid coatings used

\begin{tabular}{|c|c|c|c|}
\hline Description & Solvent & Viscosity & Name \\
\hline $\begin{array}{l}\text { Varnish resins formulated with } \\
\text { synthetic acrylic dispersion. Brown } \\
\text { color }\end{array}$ & Aqueous & $17 ”($ Ford Cup No4) & Alfa \\
\hline $\begin{array}{l}\text { Two components acrylic } \\
\text { polyurethane varnish catalyzed with } \\
\text { pure isocyanates. Brown color }\end{array}$ & Aqueous & $30^{\prime \prime}($ Ford Cup No4) & Beta \\
\hline $\begin{array}{l}\text { Transparent coating with translucent } \\
\text { mineral micro-particles. Semi- } \\
\text { transparent. }\end{array}$ & Organic & $15^{\prime \prime}($ Ford Cup No4) & $\mathrm{Mu}$ \\
\hline Satin finish skidvarnish. Brown color & Organic & 173" (Ford Cup No4) & Gamma \\
\hline $\begin{array}{l}\text { Semi-gloss polyurethane enamel } \\
\text { based aliphatic isocyanate. Gray } \\
\text { color }\end{array}$ & Organic & $2100 \mathrm{cP}$ (Brookfield) & Theta \\
\hline $\begin{array}{l}\text { Open pore finish water based pure } \\
\text { acrylic resins. Brown color }\end{array}$ & Aqueous & $500 \mathrm{cP}$ (Brookfield) & Lambda \\
\hline
\end{tabular}

The dimensions of the samples were $70 \times 85 \times 85 \mathrm{~mm}^{3}$ and 10x100x100 $\mathrm{mm}^{3}$ for the skid resistance test and film thickness, respectively. The coatings were applied on glass to observe the presence of minerals and the texture with a stereoscopic magnifying glass Nikon SMZ800 (Japan) with a zoom ratio of 6.3:1. The presence of mineral particles was determined using a plastic square mesh with apertures of $1.90 \mathrm{x}$ $2.35 \mathrm{~mm}$ by counting the number of squares in the mesh that contained mineral particles and dividing it by the total mesh area.

Before applying the coatings to the wood, the samples were sanded with half grain $\mathrm{N}^{\mathrm{o}} 100$ to 120 paper. Two coats of finish were applied by brush according to the manufactures instructions. The plane of section of the samples (tangential or radial) was noted. 
The coating retention level was calculated as the ratio between the difference in dry mass of the sample before and after application of the coating divided by the area of the samples. The mass was determined with a balance (Adventurer ProAV4102C, USA; $0.01 \mathrm{~g}$ ).

Film thickness was measured using ultrasonic equipment (PosiTector 200, DeFelsko Corporation, USA), following the standard UNE-EN ISO 2808. The result was taken as the average of three measurements.

The determination of the skid resistance was carried out according to according to UNE-ENV 12633 standards, using a friction pendulum (Portable Skid Resistance Tester, Stanley Munro, England). The samples (10 repetitions per coating) were immersed in water at $20 \pm 2{ }^{\circ} \mathrm{C}$ for 30 minutes and then were sprayed with water on the contact surface. The test sample was fixed firmly with its longest dimension in the same direction as the swinging of the pendulum, and centered with respect to the rubber flange and the axis of suspension of the pendulum. The skid resistance value for each coating and species was taken as the average value of the pendulum obtained for the 10 samples tested.

The absorption of liquid water by partial immersion in water was measured following the standard UNE-EN 1609 in 12 chestnut wood samples size 20x20x20 $\mathrm{mm}^{3}$. The samples were conditioned to $25^{\circ} \mathrm{C} / 65 \%$ RH (Ineltec, Spain) and their initial mass $\left(m_{0}\right)$ was determined (XB $120 \mathrm{~A}$ - Accurate, Switzerland; $0.001 \mathrm{~g}$ ). Water absorption was measured in the radial and tangential plane of section, placing the corresponding surface in contact with water and sealing the sides with a polyurethane compound (polyurethane adhesive MULTIFRAFT, Wurth), which was shown not to absorb water. The samples were placed in a beaker and distilled water was added until they were submerged to about 10 $\mathrm{mm}$. The mass was determined every 7 days for 28 days. The partial immersion water absorption was calculated for each sample, $\left(W_{i p}\right)$ following the equation (Eq. 1).

$$
W_{i p}=\frac{m_{t}-m_{0}}{A_{p}} \cdot 100
$$

Where mt: mass of the sample under test after partial immersion at a time $t,(\mathrm{~kg}) ; m_{0}$ : initial mass of the sample, $(\mathrm{kg})$, Ap: surface area of the bottom of the sample, $\left(\mathrm{m}^{2}\right)$.

The absorption coefficient is the slope of the linear regression of absorption versus the square root of time $\left(\mathrm{kg} \cdot \mathrm{m}^{-2} \cdot \mathrm{s}^{-0.5}\right)$.

The statistical analysis included the test of the distribution of all variables checked was tested using the Shapiro-Wilk test (accept $H_{o}$ if $p>0.05$ ) and the effect of treatments on the dependent variables was checked using the Kruskal-Wallis non-parametric test (accept $H_{o}$ if $\mathrm{p}>0.05$ ). Once the effect of the treatments was verified, a multiple comparison was performed between medians using the Wilcox test (accept $H_{o}$ if $p<0.05$ ). 


\section{RESULTS AND DISCUSSION}

It was observed that Gamma and $\mathrm{Mu}$ had a coarser texture (larger particles) with a higher presence of mineral particles, 97 and $85 \%$ respectively, followed by Theta with minerals present in $81 \%$ of the total area. Beta showed a low presence of minerals, $22 \%$, but a porous texture different to the other coatings studied. Finally, the open pore finish Lambda presented a silky texture and a very low presence of mineral particles, $6 \%$ (Figure 1)
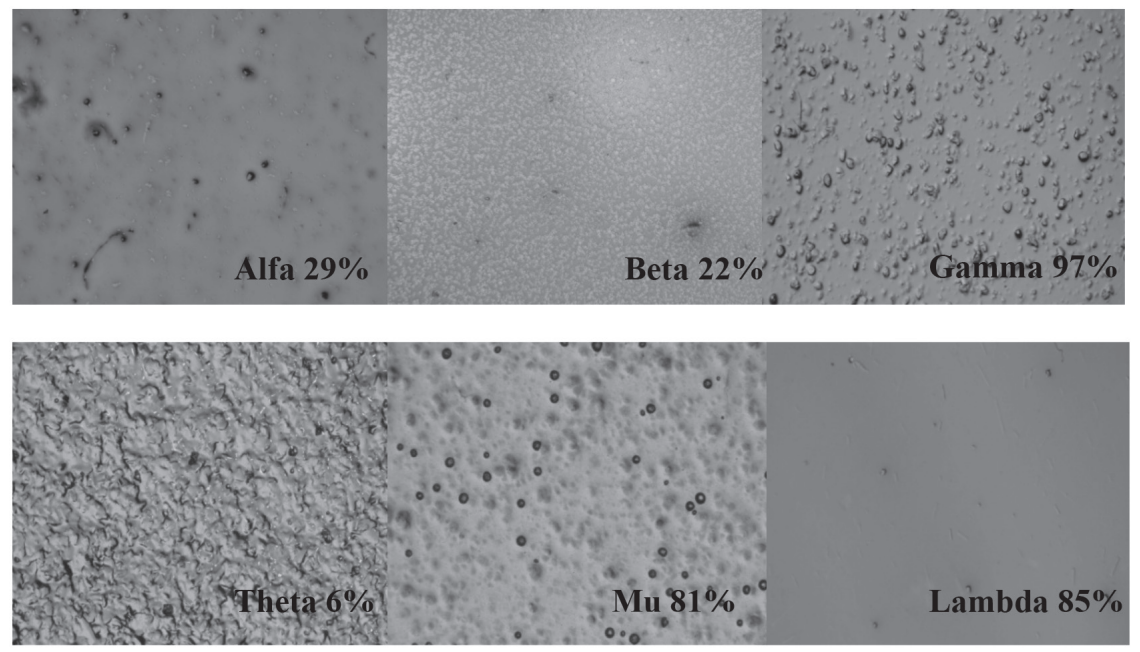

Figure 1. Detail of each coating under the stereoscopic magnifying glass (zoom 6.3:1) and presence of mineral particles.

The coating retention level did not have a normal distribution (Shapiro-Wilk $=2.2 \times 10^{-16}$ ). All coatings studied showed a significant effect on the coating retention level (Wilcox test). Additionally, all coatings presented significant differences between chestnut and pine, except open pore finish Lambda ( $p=7.5 \mathrm{E}-2$; $\mathrm{p}<0.05$ ), (Table 3 ). With the exception of the coating $\mathrm{Mu}$, all coatings showed higher coating retention level in pine than in chestnut (Table 3).

According to the type of solvent, the highest coating retention level was found for Gamma, $\mathrm{Mu}$ and Theta. These coatings have an organic solvent, and in agreement with qualitative descriptions of coating penetration showed in a previous study (de Meijer 2001), the organic solvent coatings has a deeper penetration than aqueous solvent.

The film thickness did not present a normal distribution (Shapiro-Wilk test $\mathrm{p}=2.2 \times 10-16$ ). Coatings Beta, Gamma and Lambda had a significant effect, depending on the species, on the film thickness (Wilcox $\mathrm{p}<0.05$ ). As was observed for coating retention level, the thickness of all coatings was higher in pine than in chestnut (Table 3). 
Table 3. Coating retention level and thickness for each coating. Comparison between columns significant at $p<0.05$ indicated by $(*)$.

\begin{tabular}{c|cc|cc|c}
\hline \multicolumn{6}{c}{ Coating retention level $\left(\mathrm{gm}^{-2}\right)$} \\
\hline & \multicolumn{2}{|c|}{ Pine } & \multicolumn{2}{c}{ Chestnut } & \\
\hline Coating & Average & $\begin{array}{c}\text { Standard } \\
\text { deviation }\end{array}$ & Average & $\begin{array}{c}\text { Standard } \\
\text { deviation }\end{array}$ & p-value \\
\hline Alfa & 52.66 & 15.86 & 14.50 & 11.31 & $2.6 \times 10^{-3} *$ \\
Beta & 96.88 & 36.94 & 40.11 & 13.72 & $5.0 \times 10^{-4} *$ \\
Gamma & 143.11 & 19.99 & 65.88 & 26.31 & $1.0 \times 10^{-5} *$ \\
Lambda & 37.66 & 13.90 & 27.11 & 6.83 & $7.6 \times 10^{-2}$ \\
Mu & 140.88 & 24.38 & 182.22 & 40.31 & $4.6 \times 10^{-2} *$ \\
Theta & 227.77 & 150.09 & 133.33 & 65.00 & $2.7 \times 10^{-2} *$ \\
\hline
\end{tabular}

\begin{tabular}{c|cc|cc|c}
\hline \multicolumn{6}{c}{ Level thickness $(\mu \mathrm{m})$} \\
\hline & \multicolumn{2}{|c}{ Pine } & \multicolumn{2}{c}{ Chestnut } & \\
\hline Coating & Average & $\begin{array}{c}\text { Standard } \\
\text { deviation }\end{array}$ & Average & $\begin{array}{c}\text { Standard } \\
\text { deviation }\end{array}$ & p-value \\
\hline Alfa & 50.61 & 10.35 & 48.04 & 6.16 & $2.6 \times 10^{-3} *$ \\
Beta & 66.49 & 14.83 & 55.04 & 6.50 & $5.0 \times 10^{-4} *$ \\
Gamma & 159.72 & 38.99 & 120.85 & 16.03 & $1.0 \times 10^{-5} *$ \\
Lambda & 59.88 & 6.66 & 52.30 & 6.65 & $7.6 \times 10^{-2}$ \\
Mu & 168.23 & 22.52 & 164.06 & 72.59 & $4.6 \times 10^{-2} *$ \\
Theta & 290.76 & 63.04 & 251.81 & 85.72 & $2.7 \times 10^{-2} *$ \\
\hline
\end{tabular}

The differences in coating retention level and film thickness observed in the two species can be attributed to the fact that pine has a lower density than chestnut, $4.7 \times 10^{-4} \mathrm{~kg} \cdot \mathrm{m}^{-3}$ and $5.9 \times 10^{-4}$ $\mathrm{kg} \cdot \mathrm{m}^{-3}$, respectively, and therefore a greater volume of voids. Consequently, a higher absorption of liquid can be expected. In addition, pine is of finer texture than chestnut, and with a medium grain, allowing for better preparation of the surface prior to the application of the coating.

The water absorption coefficient of chestnut wood in the radial and tangential plane was $0.0056 \pm$ $0.0010 \mathrm{~kg} \cdot \mathrm{m}^{-2} \cdot \mathrm{s}^{-0.5}$ and $0.0054 \pm 0.0013 \mathrm{~kg} \cdot \mathrm{m}^{-2} \cdot \mathrm{s}^{-0.5}$, respectively. There was no significant difference between the results of the two planes. The absorption coefficient for the chestnut was lower than that of the pine, $1.1 \times 10^{-2} \mathrm{~kg} \cdot \mathrm{m}^{-2} \cdot \mathrm{s}^{-0.5}$ (Mukhopadhyaya et al. 2002). Even though the coatings had an organic solvent base, the water absorption coefficient can be considered an indication of the mechanisms for liquid absorption which could explain the differences between chestnut and pine.

The determination of the skid resistance showed that, for both species, the coatings Gamma and $\mathrm{Mu}$ were more resistant to skid, followed by Beta. The open pore finish Lambda, which used as a reference, presented the lowest anti-skid resistance for the chestnut and one of worst for the pine. The ShapiroWilk test determined that skid resistance did not follow a normal distribution $\left(\mathrm{p}=2.2 \times 10^{-16}, \mathrm{P}>0.05\right)$. According to the Kruskal-Wallis test, the coatings had a significant effect on the skid resistance for pine and chestnut, $\mathrm{p}=3.4 \times 10^{-10}$ and $\mathrm{p}=4.6 \times 10^{-10}$, respectively. Finally, the Wilcox test analysis of the effect of coating in each species showed that coatings Beta, Gamma and Lambda had a significant higher skid resistance in pine than in chestnut (Table 4), a result also observed in the analysis of thickness (Table 3). 
Table 4. Skid resistance. Comparison between columns significant at $p<0.005$, indicated by (*).

\begin{tabular}{l|cc|cc|c}
\hline \multicolumn{6}{c}{ Skid resistance } \\
\hline & \multicolumn{2}{|c}{ Pine } & \multicolumn{2}{c}{ Chestnut } & \\
\hline Coating & Average & $\begin{array}{c}\text { Standard } \\
\text { deviation }\end{array}$ & Average & $\begin{array}{c}\text { Standard } \\
\text { deviation }\end{array}$ & p-value \\
\hline Alfa & 32.66 & 3.25 & 34.08 & 2.51 & $1.2 \times 10^{-1}$ \\
Beta & 42.08 & 6.39 & 35.25 & 4.05 & $1.5 \times 10^{-2} *$ \\
Gamma & 53.16 & 4.86 & 48.25 & 4.39 & $2.2 \times 10^{-2} *$ \\
Lambda & 22.58 & 2.51 & 19.91 & 3.38 & $4.1 \times 10^{-2} *$ \\
Mu & 47.75 & 6.91 & 49.75 & 7.55 & $4.5 \times 10^{-1}$ \\
Theta & 20.16 & 0.90 & 22.50 & 2.68 & $7.3 \times 10^{-2}$ \\
\hline
\end{tabular}

Additionally, the effect of the plane of section on the skid resistance demonstrated no significant differences. Consistently pine as a substrate presented higher values of skid resistance, coating retention level and thickness (Tables 3 and 4). The lower performance of chestnut can be attributed to the high content of extractives, which are reported to hinder the anchorage and curing of coatings (Martin 1997). Furthermore, pine has a higher water coefficient of absorption. A plausible hypothesis to explain the difference between species is that in pine the liquid component of the coating is absorbed, leaving the mineral particles exposed on the surface. Therefore, the grip function of the coating is accomplished more success fully. On the contrary, chestnut absorbs the liquid coating poorly, and the mineral particles remain within the film (Figure 2).
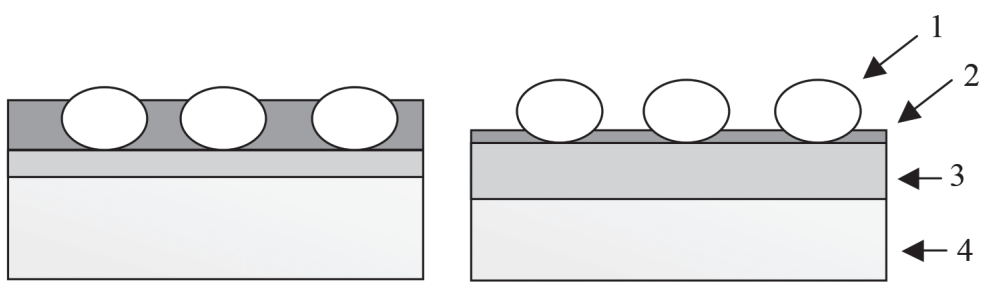

Figure 2. Diagram of the system wood-coating for chestnut (left) and pine (right).

(1) Mineral particles on the surface, (2) unabsorbed coating on the surface,

(3) absorbed coating in the wood, (4) wood sample

Additionally, Gamma and Mu had a coarser texture, with a higher concentration of mineral particles. Both coatings showed the best skid resistance, irrespective of the species. The open pore finish Lambda showed the worst results for skid resistance, confirming that the anti-skid function of coating is important to accomplish a finishing that complies with the construction regulations (Tables 3 and 4).

\section{CONCLUSIONS}

Independently of the coating tested, pine presented a higher skid resistance than chestnut. Additionally, for each coating tested thickness and coating retention level were significantly higher in pine than in chestnut, showing a better development of the film. For both species, Mu and Gamma demonstrated a coarsest texture, a higher concentration of mineral particles and the higher anti-skid resistance. Overall, this study showed that pine has a better coating performance than chestnut. Nevertheless, chestnut performs acceptably if the adequate coating system is used. Finally, the results show the importance of designing the coating according to the wood species, since wood is not an inert substrate and could seriously affect the performance of the coating. 


\section{ACKNOWLEDGMENTS}

The authors would like to thank the Ministry of Science and Innovation of Spain (MICIN) and the Plan for Science, Technology and Innovation of the Principality of Asturias (PCTI) for the funding of the research project "Forest and industrial evaluation of Spanish chestnut" (VALOCAS). The funding of this work was conducted through the lines Singular Strategic Projects (MICIN) and Complementary Support for Singular Strategic Projects carried out in Asturias (PCTI). The authors would also like to acknowledge the collaboration of the company IBERSA (Asturias, Spain).

\section{REFERENCES}

CEN. European Committee for Standardisation. 1997. Productos aislantes térmicos para aplicaciones en la edificación. Determinación de la absorción de agua a corto plazo. Ensayo por inmersión parcial. AENOR. Madrid. UNE-EN 1609. 11p.

CEN. European Committee for Standardisation. 2003. Método de la determinación del valor de la resistencia al deslizamiento/resbalamiento de los pavimentos pulidos y sin pulir. Bruselas. UNEENV 12633. 28p.

CEN. European Committee for Standardisation. 2007. Pinturas y barnices. Determinación del espesor de película. AENOR. Madrid. UNE-EN ISO 2808. 46p.

C.T.E.-D.B-S.U. 2009. Código técnico de edificación. Documento básico. Seguridad de utilización. Ministerio de Fomento. Gobierno de España. 36p.

De Meijer, M.; Thurich, K.; Militz, H. 1998. Comparative study on penetration characteristics of modern wood coatings. Wood Science and Technology 32(5): 347-365.

De Meijer, M.; Thurich, K.; Militz, H. 2001. Quantitative measurement of capillary coating penetration in relation to wood and coating properties. Holz als Roh-und Werskstoff 59(1-2):35-45

Medina, G. 2005. Pavimentos de madera. AITIM. España. 344p.

Martin, J. 1997. Acabado de la madera. Duración al exterior y temperatura de transición vítrea. AITIM - Boletín de Información Técnica. Volumen 4.

Mukhopadhyaya, P.; Kumaran, K.; Normandin, N.; Goudreau, P. 2002. Effect of surface temperature on water absorption coefficient of building materials. Institute for Research in Construction. $18 \mathrm{p}$.

Popper, R.; Niemz, P.; Eberle, G. 2005. Untersuchungen zum Sorptions- und Quellungsverhalten von thermisch behandeltem Holz. Holz Roh- Werkst 63(2):135-148.

Rijckaert, V.; Steven, M.; Van Acker, J.; de Meijer, M.; Militz, H. 2001. Quantitative assessment of the penetration of water-borne and solvent-borne wood coatings in Scot pine sapwood. Holz als Roh-und Werkstoff 59(4): 278-287.

Spalt, H.A. 1958. The fundamentals of water vapor sorption by wood. Forest Prod. J. 8(10):288-295.

Tamatir-Urias, J.C.; Borja de la Rosa, A.; Flores V, R.; Corona A, A. 2002. Vida útil de dos barnices para exteriores mediante intemperismo artificial en madera de aile, pino y encino. Revista Chapingo. Serie ciencias forestales y del ambiente. 8 (1): 83-90.

Vignote, S.; Martínez, I. 2006. Tecnología de la madera. Mundi Prensa Libros. Madrid. España. 687p.

Vignote, S.; Picos, J.; Zamora, R. 2000. Características de las principales maderas utilizadas en Bizkaia.Tecnología y aplicaciones. Berekintza, S.L. Bizkaia. España. 292p. 